\title{
Miranda
}

Revue pluridisciplinaire du monde anglophone /

Multidisciplinary peer-reviewed journal on the English-

speaking world

$14 \mid 2017$

Early American Surrealisms, 1920-1940 / Parable Art

\section{Surrealist networks: Post Surrealism and Helen Lundeberg}

Ilene Susan Fort

OpenEdition

Journals

Electronic version

URL: http://journals.openedition.org/miranda/9832

DOI: 10.4000/miranda.9832

ISSN: 2108-6559

Publisher

Université Toulouse - Jean Jaurès

Electronic reference

Ilene Susan Fort, "Surrealist networks: Post Surrealism and Helen Lundeberg", Miranda [Online], 14 I

2017, Online since 03 April 2017, connection on 16 February 2021. URL: http://

journals.openedition.org/miranda/9832 ; DOI: https://doi.org/10.4000/miranda.9832

This text was automatically generated on 16 February 2021.

\section{(c) (i) (3)}

Miranda is licensed under a Creative Commons Attribution-NonCommercial-NoDerivatives 4.0 International License. 


\title{
Surrealist networks: Post Surrealism and Helen Lundeberg
}

\author{
Ilene Susan Fort
}

Surrealism was a concept and organization that existed as a professional and social network. One of its most famous proponents, Max Ernst, noted, "Art is not produced by one artist, but by several. It is to a great degree the product of their exchange of ideas with one another" (Ernst 17). In the United States, the Post Surrealists were an early development of this exchange and as a group they expanded the network further. Despite their importance, the Post Surrealists and one of its leaders, Helen Lundeberg, have been under-investigated in surrealist literature. This paper hopes to rectify the situation somewhat by focusing on the group's ideology as demonstrated by Lundeberg's art and writings.

\section{Social Network Theory}

2 The term networking has become almost ubiquitous today due to the Internet. The terms network and networking in one of the search engines brings forth definitions, the majority of which refer to the field of telecommunications. However, the concept of a network, that is, a structure similar to a web in which an aggregate of physical or conceptual cords, wires, or other such threads connect different elements at regular intervals as a means of communication, is actually quite old. Up until the modern age, most networks were restricted by geographical boundaries and political powers. Around 1839 the term expanded to include the idea of an interlocking system as that used to transport by rivers, canals and railways. The invention of movable type, which led to the production of large supplies of inexpensive books, has long influenced the transfer of ideas. But it was the appearance of the camera and the subsequent ease of reproducing accurate images in newspapers and magazines during the late nineteenth and early twentieth centuries that further increased the expansion of pictorial knowledge. The technological development of electrical apparatus such as the 
telephone and radio in the early twentieth century expanded the concept of the network to multiple broadcasting and transformed the speed and ease of transmission.

Social networks had originally been limited to nuclear and extended families, neighborhood friends as well as occupational colleagues. A theoretical construct, social networking as a field of study is slightly more than a century old. But major developments in the field emerged in the 1930s among several disciplines, namely psychology, anthropology, and mathematics. The ethnographic studies and theoretical treatises of Bronislaw Malinowski, Alfred Radcliffe-Brown, and Claude Levi-Strauss laid the groundwork for social network theory. During the war, Levi-Strauss was one of the exiled European intellectuals. After arriving in New York City in 1941, he interacted with Andre Breton, Max Ernst and other Surrealists, their discussions later contributing to his formation of Structural Anthropology. Both his ideas and social network theory emphasized relationships rather than individuals and consequently the underlying patterns of the group or society. In the United States, Levi-Strauss participated in surrealist activities, contributing articles to the journal VVV, and joining in their games during evenings of socializing. He realized that the Surrealists' use of exquisite corpse, le jeu de la vérité, and other playful activities was a type of initiation ritual, a form of group rite (Sawin 124).

\section{Surrealist Networks}

During the period when the foundation of social network theory developed, Surrealism as an avant-garde concept was branching phenomenally beyond the borders of France, across the Atlantic Ocean to the Americas and even to Asia. Martica Sawin explained, "Surrealism left no one that came in contact with it unaffected" (Sawin xv). Actually, as early as 1959, Surrealist Marcel Jean discussed its geographic diffusion in his survey book on the movement. Jean focused on two main means of transmission beyond France: international surrealist exhibitions and publications (Jean 312-20). The travels of surrealist members, followers, and promoters were also essential to the dissemination of the aesthetic and further complicated the network emerging.

European Surrealism, the related earlier metaphysical paintings of Giorgio de Chirico, and the work of Neo-Romantics such as Charles Rain and Eugene Berman were officially introduced to the United States during the late 1920s and 1930s. The first large-scale exhibition devoted to surrealist painting outside of France occurred in 1931 in the United States, at the Wadsworth Atheneum in Hartford, Connecticut. It was preceded in the same institution the year before by an equally substantial survey devoted to NeoRomanticism. In 1932, the art dealer Julien Levy installed a smaller version of the 1931 Wadsworth Atheneum exhibition at his New York gallery. Small exhibitions, often solo displays at commercial galleries, further offered outsiders more examples of actual works for study: Levy in New York City, Katharine Kuh in Chicago, Howard Putzel and Paul Elder in San Francisco, and Lorser Feitelson, Putzel, and Stanley Rose in Los Angeles all managed commercial art galleries that catered to the avant-garde during the 1930s. At first they displayed only the work of Europeans, but later they were crucial in also promoting American exponents of Surrealism and thereby establishing new American branches of the surrealist network.

6 The movement in the United States spread rapidly and was a great deal more complicated than in France. Multiple cities became centers of activity: in addition to 
New York and nearby suburban Connecticut, far off San Francisco and Los Angeles and to a lesser degree, Chicago with its fantasy strain, were home to surrealist painters, sculptors, photographers and printmakers. Northwest Canada and the United States and later the Southwest, both Arizona and New Mexico, also attracted visitors in search of the marvelous in indigenous American culture.

7 Initially, women had been deemed by the surrealist founders as supportive personalities, existing primarily to satisfy the needs of the men, for artistic inspiration and sexual pleasure, rather than as independent creative agents. For women born in the United States as well as those that fled there during the war, the New World offered different cultures and situations for the second sex. In the United States, the lack of century-old traditions, the existence of more fluid social mores and the franchise - which women did not receive in France until 1944-encouraged their greater sense of independence and self-worth and their exploration of identity issues. That many émigré women did not flourish as Surrealists until their move to the United States demonstrates how liberating American culture was for them. Various networks of transferring intellectual concepts were therefore especially crucial conduits of information for female proponents, who had not been members of the official surrealist circle and who often never even visited Paris.

\section{Helen Lundeberg}

8 One such example was Helen Lundeberg. Little known today outside her native California, she played arguably a more significant role than Kay Sage and Dorothea Tanning in the history of Surrealism in the United States. In 1934, she and Lorser Feitelson issued the manifesto New Classicism.

The mechanisms of New Classicism are based upon the normal functioning of the mind: its meandering, logical in sequence though not in ensemble, its perceptions of analogy and idea-content in forms and groups of forms unrelated in size, time, or space. The new aesthetic form is subjective [...] an arrangement of [...] ideas. (Lundeberg, n.p.)

9 Critics soon dubbed it "Post Surrealism" because of the pictorial similarities. New Classicism would not only be the only surrealist manifesto issued by American artists in the United States, but its existence serves as a prime example of how quickly the aesthetic became integral to the nation's avant-garde. 


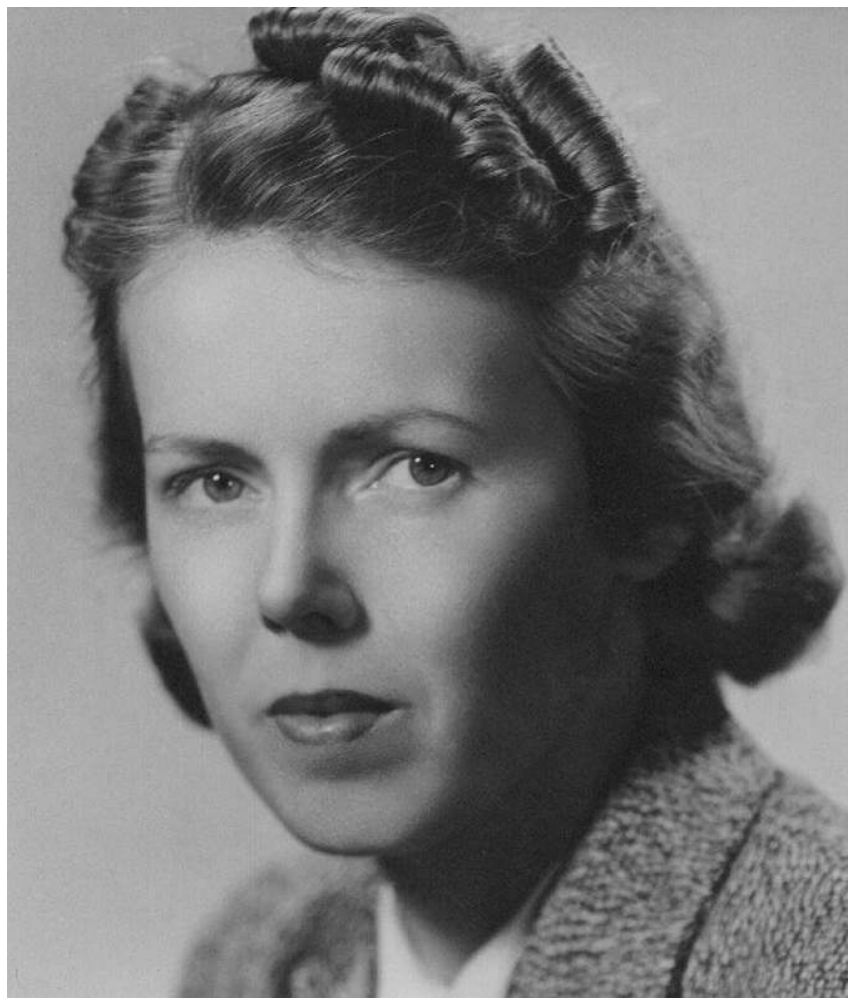

Copyright : ( ) The Feitelson / Lundeberg Art Foundation

10 Lundeberg lived in Pasadena, near Los Angeles but half a world from Paris. When the manifesto appeared, she had not traveled abroad, nor even to New York City. But she was well versed in the principles of the European aesthetic. Barely out of art school, she had studied and worked with Feitelson, a teacher at the Stickney Memorial School of Art in Pasadena and one of the most knowledgeable and radical painters in Southern California. Before his move to Los Angeles in 1927, he had traveled several times to France and Italy during that decade and worked in New York City, exhibiting at the modernist-oriented Daniel Gallery. It was Feitelson who early on introduced Lundeberg to the concepts of Surrealism and encouraged her to write the manifesto.

11 The Post Surrealists would eventually include other California-based painters, such as Dorr Bothwell, Grace Clements, Philip Guston (still known as Philip Goldstein), Reuben Kadish, and Knud Merrild. As a group, they would exhibit in 1935 at the San Francisco Museum of Art (now San Francisco Museum of Modern Art) and in 1936 at the Brooklyn Museum of Art. The latter showing introduced their art to New Yorkers and led to Lundeberg, Feitelson and Merrild receiving an invitation to participate in what would become a landmark exhibition of Surrealism, Fantastic Art, Dada, Surrealism, which opened a few months later at the Museum of Modern Art (MoMA) in New York City. The MoMA exhibition is usually discussed only in terms of New York art circles, but a touring version, Fantastic Art: Past and Present, traveled throughout the East and Midwest United States, visiting Binghamton, New York; Middlebury, Vermont; Atlanta, Georgia ; Grand Rapids, Michigan ; and Milwaukee, Wisconsin, extending the network of Surrealism (fig. 2). 
Tour of Fantastic Art: Past and Present

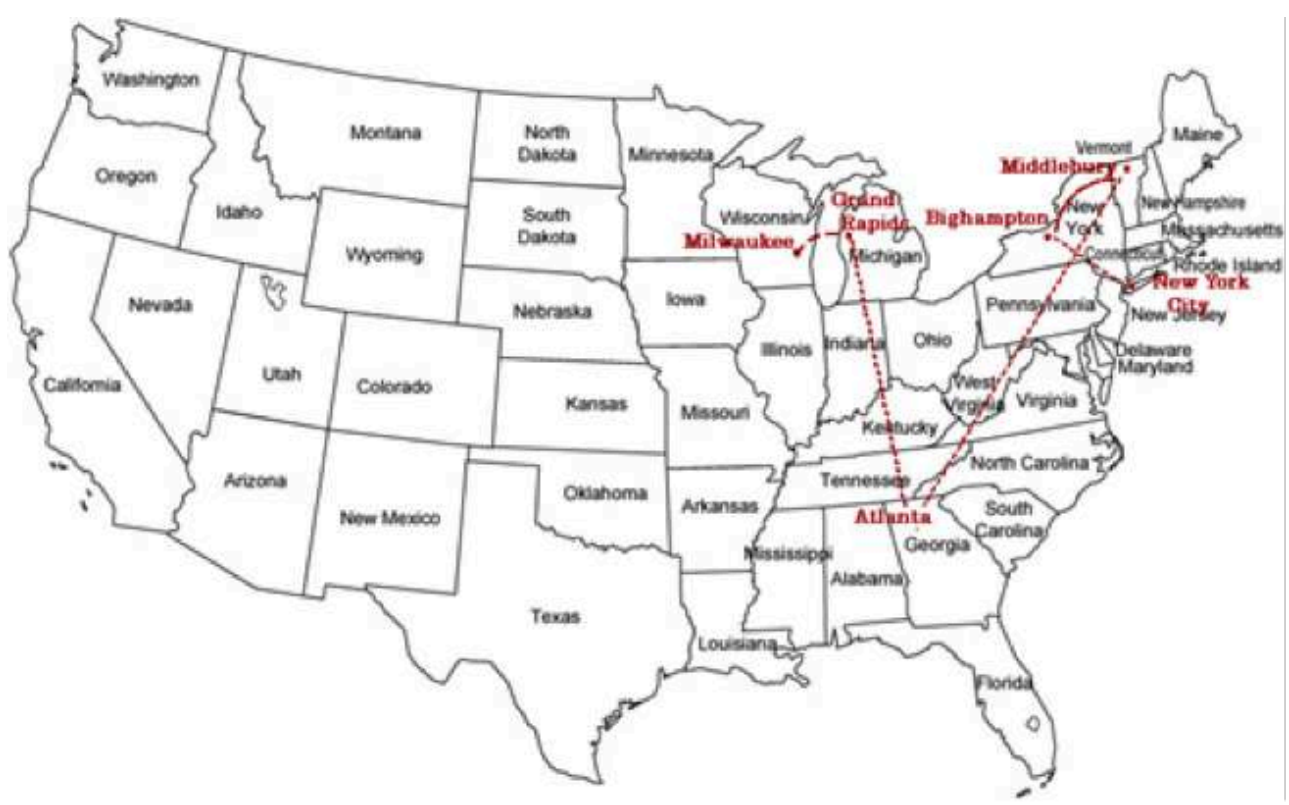

12 It established a precedent adopted later when two other institutions organized traveling surrealist exhibitions (San Francisco Museum of Art, 1944, and Art Institute of Chicago, 1947; the AIC show toured the country under the auspices of the American Federation of Arts).

\section{The Painting Plant and Animal Analogies}

13 A single painting was illustrated in the New Classicism broadside, Lundeberg's Plant and Animal Analogies. 
Helen Lundeberg (1908-1999). Plant and Animal Analogies

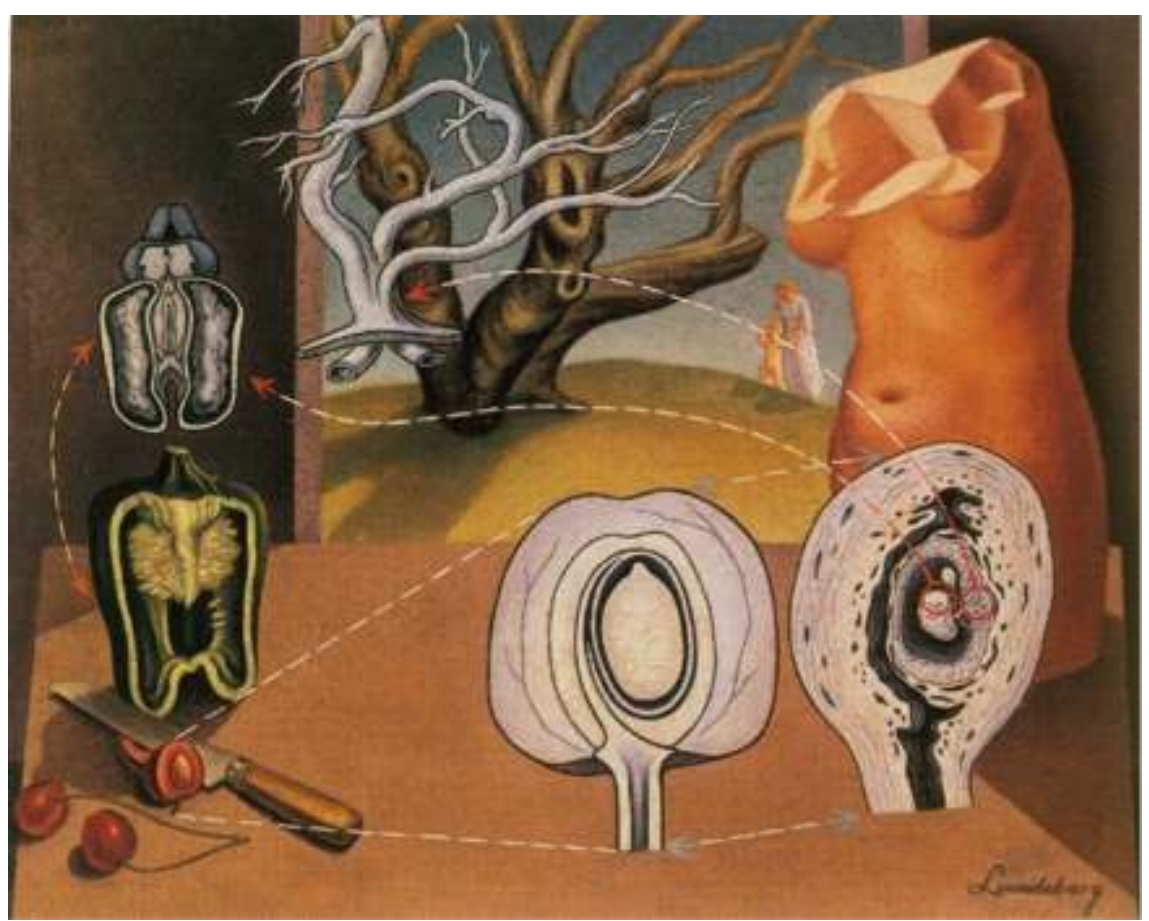

1934-35, oil on Celotex, 24 x 30 in. (61 x 76.2 cm), University of California, Irvine, Gerald Buck Collection

PHOTO: () FEITELSON LUNDEBERg FOUNDATION.

In many ways it echoes the appearance, process, and function of a network structure. A sculpted torso, knife, green pepper, and red cherries sit on a window ledge as several black-and-white diagrams float mysteriously above, and a child and mother walk in a distant landscape near a tree (the figures were added later). In Plant and Animal Analogies, and in other paintings by Lundeberg, the collage of diverse forms often concerns concepts of creation and life, from the seeds of a piece of fruit to the reproductive cells of a human being. White dashes and red and blue arrows connect the diagrams with the realistically delineated objects. They constitute the framework of the painting, assisting the viewer in understanding the meaning of the scene. Functioning as dendrites between the objects in this mysterious still life, they transmit ideas and, along with the synaptic objects, function as a whole to establish new meanings. The lines not only lead the viewer's eye through the painting but also connect the seemingly diverse and disparate objects to form a conceptual network of items that together constitute what Lundeberg defined as an "intellectual-entity."

At the time of the Post Surrealists' Brooklyn showing, Lundeberg's colleague Clements wrote about the movement in the American Marxist art journal Art Front, thereby spreading the theory of the West Coast version of Surrealism to a national audience and to one of a political character. Although believing that European Surrealism answered the need for a revolutionary art through the concept of association and the process of montage, she insisted that only Post Surrealism remedied what the Post Surrealists considered the European's lack of aesthetic unity. She went on to explain that the new art would solve this need by "cerebrally parallel[ing] the scientific and psychological contributions of our time" (Art Front 8). 

appreciation of and belief in the need for reason, order, and theory. As she explained in the manifesto,

In formulating the principles of New Classicism we [Feitelson and Lundeberg] have developed a veritably new and unprecedented aesthetic order. Balance, rhythm, unity, are not abandoned, but are attained through entirely new means. The "unity experience" becomes wholly introspective; rhythm is experienced through contemplation of the relations and sequences of forms and groups of forms. (New Classicism n.p.)

Working similar to the pathways of the brain, Post Surrealist compositions strove to underscore the concepts of structure and order.

While in college, Lundeberg studied various scientific disciplines. It was probably during this time that she became aware of textbooks with detailed black-and-white line drawings. Created by artists with special knowledge of the natural sciences and medicine, these illustrations served in the place of photographs and were intended to be accurate. Lundeberg presented four objects in Plant and Animal Analogies as such black-and-white diagrams, copying three of them almost exactly from Adam M. Miller's line illustrations in Frederick R. Bailey's Textbook of Embryology (1921). For instance, the black-and-white object above the sliced green pepper is the dorsal view of the brain of a three-month human fetus.

Adam M. Miller, Dorsal view of the brain of a three-month-old human fetus.

to some, there is a fusion of the striatum, the medial wall of the hemisphere and the anterior part of the thalamus. According to others, the increase in bulk of

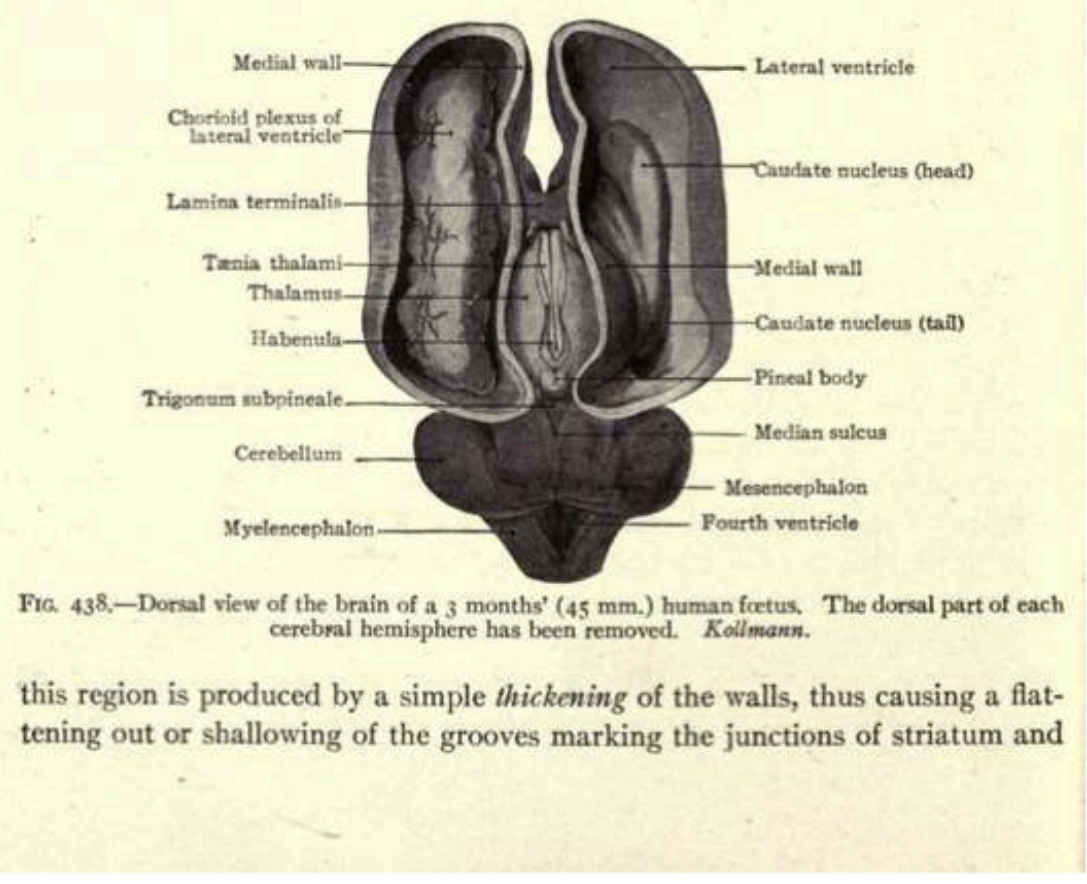

1921. In Frederick R. Bailey's Textbook of Embryology

In her canvas, she turned the drawing upside down to echo the basic outline shape of the pepper below. As she explained, "The conceptive or diagrammatic forms conditioned introspectively by the visually perceived forms are related to each other 
intellectually in their logical sequence by diagrammatic arrows and dotted line" (New Classicism, n.p.). The individual objects at first do not seem to relate to one another. Although they are clearly delineated they are not easily understood as an ensemble. The objects constitute an enigma, the element of mystery so important to Surrealism. After serious contemplation the viewer may discern the similarity of shapes, especially their outlines, such as the open red cherry with a single pit, the black-and-white diagram with a similar seed-like center and another line drawing of a uterus with a five-week-old embryo.

Helen Lundeberg (1908-1999). Plant and Animal Analogies (detail)

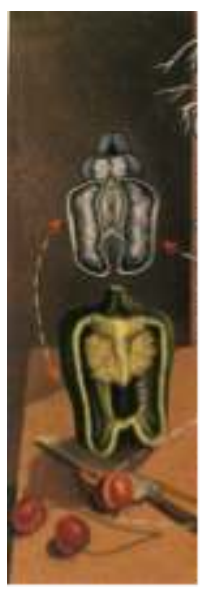

Plant and Animal Analogies is the only painting in which Lundeberg added dash lines and arrows to lead the viewer's eye around the composition. We may assume she did so because of the didactic nature of the painting. Also the only painting reproduced in the brochure of the manifesto, it serves as a model of how to read post-surrealist imagery. The still life is a narrative, but as often with Surrealism, it is not presented in a linear fashion. There is no beginning, nor end. Its format is opposite to how a viewer reads the sequential structure of frames of a film negative or panels of a mural, which usually (in Western culture) are read from left to right in a consecutive manner. (Interestingly, soon after creating this painting, Lundeberg would go on to work for the Federal Art Project / Works Progress Administration as a muralist.) The lines and arrows serve as a multivalent framework for reading the painting. There is no single system for understanding the imagery, as the dashed lines often have multiple trajectories and result in multiple permutations for understanding the entire ensemble. Lundeberg's pictorial structure accords with Roland Barthes' concept of narrative, more as a "constellation" of "contiguous fragments" (Felluga, "Introduction to Narratology"). This plurality of codes invites the viewer to delve into its alternate meanings and connotations.

The message of what the viewer understands is modified by the performance of reading the objects and the order of such a reading, as he or she brings to the process his/her own personal and cultural experiences. Thus every viewer of the painting interprets the imagery differently. In this respect Lundeberg's framework of her images and the process of relating one to another accords completely with Barthes' analysis of the process of interpretation: "In this ideal text, the networks are many and interact, without any one of them being able to surpass the rest; this text is a galaxy of signifiers; not a structure of signifieds; it has no beginning; it is reversible; we gain access to it by 
several entrances, none of which can authoritatively declared to be the main one" (Barthes $S / Z, 5$ ).

\section{Relationship to Situationists maps}

The overall structure of the arrangement of objects and connective lines in Plant and Animal Analogies also has a remarkable pictorial similarity to the navigational systems in the urban maps of Situationism.

Guy Debord (1931-1994) and Asger Jorn (1914-1973). Guide psychogéographique de Paris : discours sur les passions de l'amour

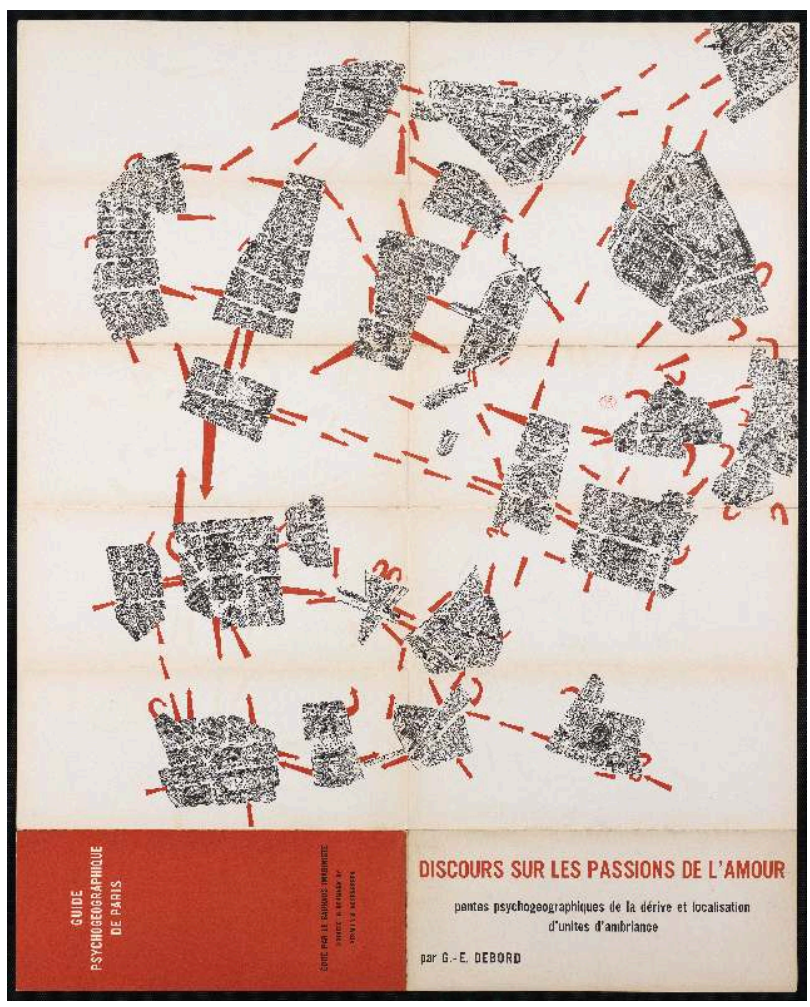

1956

In 1956 and 1957, French theorist Guy Debord and Danish painter Asger Jorn pursued mapping cities based on the psychogeographic concept of "drift" (dérive), wandering around, seemingly at random, to determine which neighborhoods had been spoiled by contemporary bureaucracy. Rather than detailing streets based on rational Cartesian philosophy, the two artists focused on neighborhoods reflecting social considerations, and then created their maps from scraps of old and contemporary maps and books, arranging them haphazardly on a sheet of paper, then adding dotted/dashed lines and arrows to connect the districts. Their cluster maps were intended to underscore patterns of associations and identity, and ultimately demonstrate how modernity had fragmented city life. Through the subtitle of one of their maps, "a discourse on the passions of love," Debord and Jorn suggested that their ultimate source was André Breton's excursions through Paris, as he described his love affair in the novel Nadja (Sadler 86). The maps were originally collages (later reproduced as prints), constructed in a manner similar to Lundeberg's process of placing the objects in her still life 
painting, part accidental and part intentional, both subjective and objective. Ultimately, Lundeberg undermined traditional still life in a manner analogous to the Situationists' concept of détournement, diverting the conventional way of reading imagery.

Lundeberg and Feitelson functioned in a manner analogous to the diagrammatic lines of her painting, for they became major links to and within the United States in the large network that extended the aesthetic of Surrealism: Feitelson beginning in New York, to Paris, back to New York, and then to Los Angeles during the 1920s; Lundeberg in the early 1930s adopted the network in Pasadena, then along with others from California introduced Post Surrealism to Los Angeles, San Francisco, and New York City. The Post Surrealist strand of the American Surrealist network was one of the earliest links to the French aesthetic. Most historians date the flourishing of Surrealism in North America to the 1940s and attribute its cause to the world war and the physical displacement of European intellectuals. However, the activities and art of the Post Surrealists demonstrate that the basic concepts of Surrealism had in the preceding decade already reached the Pacific Coast, been modified, and begun to impact the course of art throughout the United States.

I would like to thank Dr. Patricia Allmer of Edinburgh University and Dr. Terri Geis of Pomona College for reading earlier versions of this text and for their suggestions.

\section{BIBLIOGRAPHY}

American Heritage Dictionary of the English Language. Boston: Houghton Mifflin, 1969.

Bailey, Frederick Randolph and Adam Marion Miller. Textbook of Embryology. 4th ed. New York: William Wood and Co., 1921.

Barthes, Roland. S/Z. Paris: Editions du Seuil, 1970. Trans. Richard Miller. Preface Richard Howard. New York: Farrar, Straus and Giroux, Inc., 1974.

Clements, Grace. "New Content - New Form.” Art Front 2 (March 1936): 8-9.

Ernst, Max. Quoted in "Eleven Europeans in America." Museum of Modern Art Bulletin 13, 4-5 (September 1946): 2-39.

Felluga, Dino. "Introduction to Narratology: Modules on Barthes - On Plotting." Introductory Guide to Critical Theory. Purdue University. http://www.cla.purdue.edu/english/theory.

Jean, Marcel. History of Surrealist Painting. New York: Grove, 1967.

Lundeberg, Helen. New Classicism. Los Angeles: privately printed, 1934. Repr. in Helen Lundeberg, An 80th Birthday Celebration. Intro. Ilene Susan Fort. Los Angeles: Los Angeles County Museum of Art/American Art Council, 1988.

Sadler, Simon. The Situationist City. Cambridge, Massachusetts: MIT Press, 1998.

Sawin, Martica. Surrealism in Exile and the Beginning of the New York School. Cambridge, Massachusetts: MIT Press, 1995. 


\section{ABSTRACTS}

This paper demonstrates how surrealist aesthetics spread to the United States from Europe through a system of cultural and social networking, and hence emerged in southern California in the mid-1930s, years before the usual dating of the aesthetic in the Americas to the early 1940s when European Surrealists fleeing the war emigrated to New York City. In Los Angeles in the early 1930s, Helen Lundeberg along with Lorser Feitelson organized a movement first called "New Classicism," but dubbed by the critics "Post Surrealism." The manifesto which Lundeberg wrote was illustrated by her painting Plant and Animal Analogies, and together text and image demonstrated her belief in the need to infuse Surrealism with structure. The seemingly haphazard arrangement of still life elements in the painting along with its collage effect demonstrate Guy Debord's and the Situationists' principles of mapping known as drift (dérive) and diversion (détournement). Plant and Animal Analogies should be considered an icon in the history of Surrealism.

Cet article étudie le rôle des réseaux culturels et sociaux dans la diffusion de l'esthétique surréaliste aux Etats-Unis. On s'intéressera plus précisément à son émergence dans le sud de la Californie dès le milieu des années trente, soit plusieurs années avant l'arrivée des exilés surréalistes européens à New York, au début des années quarante. A Los Angeles, quelque dix ans plus tôt, un mouvement s'organise sous l'impulsion d'Helen Lundeberg et Lorster Feitelson : le "New Clacissism » qui devient sous la plume de la critique le « Post-surréalisme ». Le manifeste rédigé par Lundeberg et illustré par Plant and Animal Analogies (1934-35) souligne la nécessité d'ordonner et de structurer la représentation picturale surréaliste. La composition, apparemment anarchique, d'éléments inanimés, s'associe à des effets de collage dans une représentation préfigurant la carte pyschographique de Guy Debord (1957) et les principes situationnistes de la dérive et du détournement. De ce point de vue, Plant and Animal Analogies peut être considéré comme une véritable icône de l'histoire du Surréalisme.

INDEX

Keywords: post surrealism, surrealism, new classicism, social network theory, women artists, American surrealism, Plant and Animal Analogies, Situationist International

Mots-clés: post-surréalisme, surréalisme, nouveau classicisme, théorie des réseaux sociaux, femmes artistes, surréalisme américain, Plant and Animal Analogies, situationnisme

\section{AUTHORS}

\section{ILENE SUSAN FORT}

Senior Curator, The Gail and John Liebes Curator of American Art

Los Angeles County Museum of Art

ifort@lacma.org 